\title{
Correction: A national survey of the provision of ultrasound surveillance for the detection of hepatocellular carcinoma
}

Cross J, Villaneuva A, Shetty S, et al. A national survey of the provision of ultrasound surveillance for the detection of hepatocellular carcinoma. Frontline Gastroenterol 2016;7:82-9. doi: 10.1136/flgastro-2015-100617

The second author's name should read as A Villanueva.

(c) Author(s) (or their employer(s)) 2018. No commercial re-use. See rights and permissions. Published by BMJ.

Frontline Gastroenterology ;10:87. doi:10.1136/flgastro-2015-100617corr1

A) Check for updates 